\title{
Panowamycins A and B, new antitrypanosomal isochromans produced by Streptomyces sp. K07-0010
}

\author{
Junko Hashida $^{1}$, Megumi Niitsuma ${ }^{1}$, Masato Iwatsuki ${ }^{1}$, Mihoko Mori ${ }^{2}$, Aki Ishiyama ${ }^{1}$, Miyuki Namatame ${ }^{1}$, \\ Aki Nishihara-Tsukashima ${ }^{1}$, Atsuko Matsumoto ${ }^{2}$, Ismet Ara $^{2}$, Yoko Takahashi ${ }^{2}$, Haruki Yamada ${ }^{2}$, \\ Kazuhiko Otoguro ${ }^{1}$, Kazuro Shiomi ${ }^{2}$ and Satoshi Ōmura ${ }^{2}$
}

Two new isochromans, panowamycins A and B, were purified by solvent extraction, silica gel and octadecylsilyl silica gel (ODS) column chromatography followed by preparative HPLC, from a culture broth of Streptomyces sp. K07-0010, together with the known compounds NFAT-133, conglobatin, piericidin C series and dinactin. Structures of panowamycins were elucidated as new analogs of NFAT-133 by spectroscopic studies including various NMR experiments. Panowamycins A and B showed moderate antitrypanosomal activity, with $\mathrm{IC}_{50}$ values of 0.40 and $3.30 \mu \mathrm{g} \mathrm{ml}^{-1}$, respectively.

The Journal of Antibiotics (2012) 65, 197-202; doi:10.1038/ja.2011.139; published online 25 January 2012

Keywords: isolation; panowamycin; Streptomyces; structure; trypanosoma

\section{INTRODUCTION}

Human African Trypanosomiasis, also known as sleeping sickness, is caused by two subspecies of the parasitic protozoan, Trypanosoma brucei. Unique to Africa, Human African Trypanosomiasis has, in past epidemics, caused significant and widespread mortality and morbidity. The World Health Organization estimated that Human African Trypanosomiasis caused 54000 deaths in 2008, projecting a continuing fall to a total of 36000 in $2015 .{ }^{1}$ Even though cases are in steep decline and the disease may possibly be eliminated in the near future, significant problems remain with the four parenteral drugs commonly used for treatment (suramin, pentamidine, eflornithine, melarsoprol), as well as the newly introduced nifurtimox. All are toxic, expensive, difficult to administer, have difficulty in crossing the blood/brain barrier and parasite resistance to them is increasing. However, only one molecule (fexinidazole) is currently in clinical development for treatment of Human African Trypanosomiasis. ${ }^{2}$ Therefore, there is an urgent need for new antitrypanosomal drugs that are more effective, safer, affordable, easier to use and that, ideally, have a novel mode of action and can thus cross the blood/brain barrier safely to treat the more deadly late-stage diseases.

Our research group has focused on the screening of antitrypanosomal agents from microbial metabolites. ${ }^{3-5}$ Our ongoing studies have led to the discovery of two novel NFAT-133 analogs, panowamycins A (1) and B (2) isolated from a culture broth of Streptomyces sp. K07-0010, along with NFAT-133 (3), ${ }^{6}$ conglobatin $(4),{ }^{7}$ piericidins $\mathrm{C}_{1}-\mathrm{C}_{4}(\mathbf{5}-\mathbf{8})^{8}$ and dinactin $(\mathbf{1 1})^{9}$ (Figure 1). In this paper, the taxonomy of the producing strain, fermentation, isolation, physicochemical properties and structure elucidation of $\mathbf{1}$ and $\mathbf{2}$, and antitrypanosomal activities of isolated compounds are described.

\section{RESULTS}

Taxonomy of the producing strain K07-0010

Strain K07-0010 was isolated from mangrove soil collected at Kasturi Ghat, Cox's Bazar (other name 'Panowa'), Bangladesh. The vegetative mycelia developed well on yeast extract-malt extract agar, oatmeal agar and others, and did not show fragmentation into coccoid forms or bacillary elements. The color of vegetative mycelia was yellow to brown. Aerial mycelia were produced poorly on inorganic salts-starch agar, glycerol-asparagine agar and others, and the aerial mass color was white to gray. The mature spore chains were spiral and each had more than 20 spores per chain. The spores were cylindrical in shape, $1.0-1.1 \times 0.5-0.7 \mu \mathrm{m}$ in size and had a hairy surface (Figure 2). No soluble pigment was produced. The isomer of diaminopimelic acid in whole-cell hydrolysates of strain K07-0010 was determined to be LL-form. An almost complete $16 \mathrm{~S}$ rDNA sequence (1450 nucleotides) was determined. The result of the identification analysis by EzTaxon. org server version $2.1^{10}$ showed the strain belongs to the genus Streptomyces and relates closely to Streptomyces kasugaensis M338$\mathrm{M1}^{\mathrm{T}}$ (AB024441, 98.4\%). Based on the morphological and cultural properties and 16S rDNA sequence similarity, the strain K07-0010 was identified as a Streptomyces species ${ }^{11}$ and designated Streptomyces sp. K07-0010.

\section{Isolation}

The procedure for isolation of $\mathbf{1}$ and $\mathbf{2}$ is summarized in Scheme 1. All compounds were obtained by bioassay-guided purification. The 6-day-old culture broth (31) was added to an equal amount of ethanol and then filtered. The filtrate was concentrated under reduced pressure to remove ethanol and the aqueous solution was extracted three times

${ }^{1}$ Research Center for Tropical Diseases, Kitasato Institute for Life Sciences, Kitasato University, Tokyo, Japan and ${ }^{2}$ Kitasato Institute for Life Sciences and Graduate School of Infection Control Sciences, Kitasato University, Tokyo, Japan

Correspondence: Professor K Shiomi or Professor S Ōmura, Kitasato Institute for Life Sciences, Kitasato University, 5-9-1 Shirokane, Minato-ku, Tokyo 108-8641, Japan. E-mail: shiomi@lisci.kitasato-u.ac.jp or omuras@insti.kitasato-u.ac.jp

Received 5 October 2011; revised 12 December 2011; accepted 21 December 2011; published online 25 January 2012 
<smiles>CC(=O)C(C)[C@H]1O[C@H](CCO)c2cc(C)ccc2[C@H]1C</smiles>

Panowamycin A (1)<smiles>Cc1ccc2c(c1)[C@@H](C)[C@H](C(C)C(C)O)O[C@H]2C</smiles>

Panowamycin B (2)<smiles>Cc1ccc(C(C)C(O)C(C)C(C)O)c(/C=C/CO)c1</smiles>

NFAT-133 (3)<smiles>CC(C)=CC(C)=C[C@@H](C)C[C@@H](C)[C@@H](Cc1cnco1)OC(=O)C(C)=C[C@@H](C)C[C@@H](C)[C@@H](Cc1cnco1)OC(=O)C(C)=CC(C)C</smiles>

Conglobatin (4)<smiles>[R]C1OC1(C)[C@](O)([C@@H](C)/C=C(C)/C=C(\[B])C/C(C)=C/Cc1nc(OC)c(OC)c(O)c1C)[C@@H]1CO1</smiles>

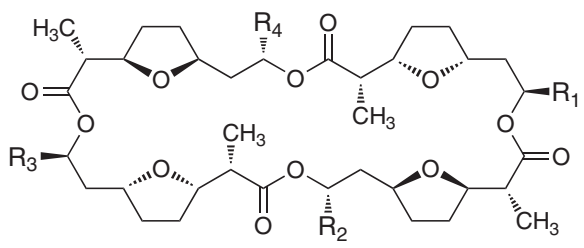

\begin{tabular}{rcc}
\hline Piericidin & $\mathrm{R}_{1}$ & $\mathrm{R}_{2}$ \\
\hline $\mathrm{C}_{1}(\mathbf{5})$ & $\mathrm{H}$ & $\mathrm{CH}_{3}$ \\
$\mathrm{C}_{2}(\mathbf{6})$ & $\mathrm{CH}_{3}$ & $\mathrm{CH}_{3}$ \\
$\mathrm{C}_{3}(\mathbf{7})$ & $\mathrm{H}$ & $\mathrm{CH}\left(\mathrm{CH}_{3}\right)_{2}$ \\
$\mathrm{C}_{4}(\mathbf{8})$ & $\mathrm{CH}_{3}$ & $\mathrm{CH}\left(\mathrm{CH}_{3}\right)_{2}$ \\
\hline
\end{tabular}

\begin{tabular}{lcccc}
\hline & $\mathrm{R}_{1}$ & $\mathrm{R}_{2}$ & $\mathrm{R}_{3}$ & $\mathrm{R}_{4}$ \\
\hline Nonactin (9) & $\mathrm{CH}_{3}$ & $\mathrm{CH}_{3}$ & $\mathrm{CH}_{3}$ & $\mathrm{CH}_{3}$ \\
Monactin (10) & $\mathrm{CH}_{2} \mathrm{CH}_{3}$ & $\mathrm{CH}_{3}$ & $\mathrm{CH}_{3}$ & $\mathrm{CH}_{3}$ \\
Dinactin (11) & $\mathrm{CH}_{2} \mathrm{CH}_{3}$ & $\mathrm{CH}_{3}$ & $\mathrm{CH}_{2} \mathrm{CH}_{3}$ & $\mathrm{CH}_{3}$ \\
Trinactin (12) & $\mathrm{CH}_{2} \mathrm{CH}_{3}$ & $\mathrm{CH}_{2} \mathrm{CH}_{3}$ & $\mathrm{CH}_{2} \mathrm{CH}_{3}$ & $\mathrm{CH}_{3}$ \\
Tetranactin (13) & $\mathrm{CH}_{2} \mathrm{CH}_{3}$ & $\mathrm{CH}_{2} \mathrm{CH}_{3}$ & $\mathrm{CH}_{2} \mathrm{CH}_{3}$ & $\mathrm{CH}_{2} \mathrm{CH}_{3}$ \\
\hline
\end{tabular}

Figure 1 Structures of panowamycins A (1) and B (2) and known compounds isolated from a culture broth of K07-0010.

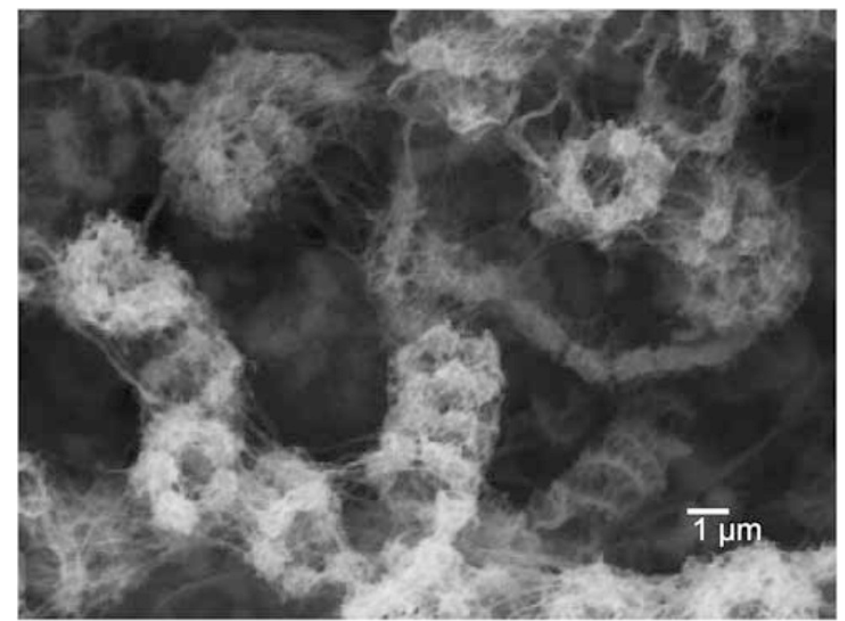

Figure 2 Scanning electron micrograph of Streptomyces sp. K07-0010.

with ethyl acetate (31). The organic layer was dried over $\mathrm{Na}_{2} \mathrm{SO}_{4}$ and concentrated to dryness in vacuo to afford a crude material $(1.75 \mathrm{~g})$. The ethyl acetate extract $(1.69 \mathrm{~g})$ was applied to silica gel column chromatography, which was eluted with each $550 \mathrm{ml}$ of a mixture of $\mathrm{CHCl}_{3}-\mathrm{MeOH}(100: 0,100: 1,50: 1,10: 1,1: 1,0: 100)$ in this order. The $\mathrm{CHCl}_{3}-\mathrm{MeOH}$ (100:1) fraction (272 mg of $359 \mathrm{mg}$ ) was applied to an octadecylsilyl silica gel (ODS) column chromatography. It was eluted with 20, 40, 50, 60, 70, 80, 90 and $100 \% \mathrm{CH}_{3} \mathrm{CN}$ (each $7 \mathrm{ml} \times 3$ fractions). The third $40 \%$ aq. $\mathrm{CH}_{3} \mathrm{CN}$ eluate and the first and second $50 \% \mathrm{CH}_{3} \mathrm{CN}$ eluate $(10.2 \mathrm{mg})$ were dissolved in a small amount of $\mathrm{MeOH}$ and applied to a preparative HPLC (Pegasil ODS, 20 i.d. $\times 250 \mathrm{~mm}$ ) with $60 \% \mathrm{MeOH}$ (flow rate, $5.0 \mathrm{ml} \mathrm{min}^{-1}$; detection, UV $210 \mathrm{~nm}$ ). The peaks with retention times of 58 and $64 \mathrm{~min}$ were collected and concentrated in vacuo to dryness to afford $\mathbf{1}(1.7 \mathrm{mg})$ and $\mathbf{2}(2.1 \mathrm{mg})$, respectively.
The second $60 \% \mathrm{CH}_{3} \mathrm{CN}(6.6 \mathrm{mg})$ of the ODS column consists of pure 4. The combined crude mixture of $70,80,90$ and $100 \% \mathrm{CH}_{3} \mathrm{CN}$ $(161.7 \mathrm{mg}$ ) was separated by HPLC (Pegasil ODS, 20 i.d. $\times 250 \mathrm{~mm}$ ) with $90 \% \mathrm{MeOH}$ (flow rate, $5.0 \mathrm{ml} \mathrm{min}^{-1}$; detection, UV $210 \mathrm{~nm}$ ), giving piericidins $C_{1}(5$, r.t. $=17 \mathrm{~min}, 11.4 \mathrm{mg}), C_{2}(6$, r.t. $=19 \mathrm{~min}$, $16.0 \mathrm{mg}), \mathrm{C}_{3}(7$, r.t. $=22 \mathrm{~min}, 39.2 \mathrm{mg})$ and $\mathrm{C}_{4}(\mathbf{8}$, r.t. $=24 \mathrm{~min}, 38.0 \mathrm{mg})$ as yellow powder. Compound $3(9.0 \mathrm{mg})$ was isolated as a white powder from the eluate of $\mathrm{CHCl}_{3}-\mathrm{MeOH}$ (50:1) fraction (173.4 mg) of the silica gel column by a preparative HPLC (Pegasil ODS, 20 i.d. $\times 250 \mathrm{~mm}$ ) with $40 \% \mathrm{CH}_{3} \mathrm{CN}$. A member of the macrotetrolide polynactins, 11, was isolated from the $\mathrm{CHCl}_{3}-\mathrm{MeOH}$ (1:1) fraction $(255 \mathrm{mg})$ followed by LH-20 gel filtration column chromatography and trituration with $\mathrm{MeOH}$.

\section{Physico-chemical properties}

The physico-chemical properties of $\mathbf{1}$ and $\mathbf{2}$ are summarized in Table 1 . They are readily soluble in $\mathrm{CHCl}_{3}$ and $\mathrm{MeOH}$. They showed absorption maxima at 218 and $276 \mathrm{~nm}$ in UV spectra. The broad IR absorption at $3400 \mathrm{~cm}^{-1}$ of $\mathbf{1}$ and 2 suggested the presence of hydroxyl groups, and the sharp IR absorption at $1700 \mathrm{~cm}^{-1}$ of 1 suggested the presence of ketone groups. The similarity in physico-chemical properties strongly suggested that they are structurally related to 3 .

\section{Structure elucidation of 2}

The molecular formula of 2 was elucidated by HR-FAB-MS to be $\mathrm{C}_{17} \mathrm{H}_{26} \mathrm{O}_{3}$, requiring five degrees of unsaturation. The ${ }^{1} \mathrm{H}$ and ${ }^{13} \mathrm{C}$ NMR spectra data $\left(\mathrm{CDCl}_{3}\right)$ of 2 are listed in Table 2. The ${ }^{13} \mathrm{C}$ NMR and HSQC spectra indicated 17 carbons, which were classified into three $s p^{2}$ quaternary carbons, three $s p^{2}$ methine carbons, three oxygenated $s p^{3}$ methine carbons, two $s p^{3}$ methine carbons, one oxygenated $s p^{3}$ methylene carbon, one $s p^{3}$ methylene carbon and four methyl carbons. The ${ }^{1} \mathrm{H}$ and ${ }^{13} \mathrm{C}$ NMR spectra suggested the presence of a 1,2,4-trisubstituted benzene ring by the coupling pattern 


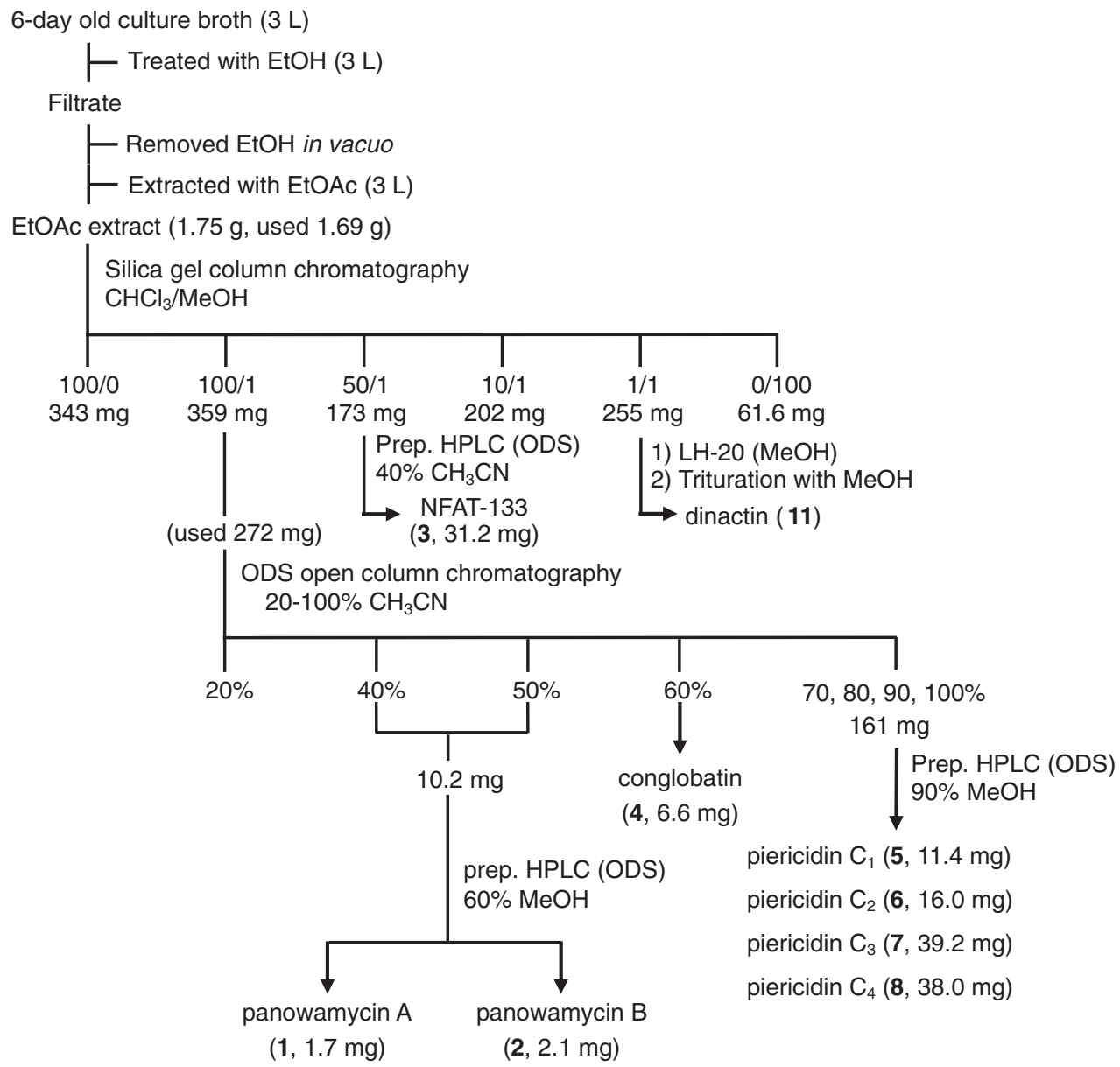

Scheme 1 Purification of panowamycins A (1) and B (2).

Table 1 Physico-chemical properties of panowamycins A (1) and B (2)

\begin{tabular}{|c|c|c|}
\hline & Panowamycin A (1) & Panowamycin B (2) \\
\hline Appearance & Light yellow amorphous solid & Light yellow amorphous solid \\
\hline$[\alpha] D^{25}(\mathrm{MeOH})$ & $-49.4^{\circ}($ c 0.1$)$ & $-61.6^{\circ}($ c 0.1$)$ \\
\hline Molecular formula & $\mathrm{C}_{17} \mathrm{H}_{24} \mathrm{O}_{3}$ & $\mathrm{C}_{17} \mathrm{H}_{26} \mathrm{O}_{3}$ \\
\hline \multirow[t]{2}{*}{ HR-ESI-MS ( $m / z)$} & Found: $277.1803[\mathrm{M}+\mathrm{H}]^{+}$ & Found: $279.1959[\mathrm{M}+\mathrm{H}]^{+}$ \\
\hline & Calcd: 277.1804 for $\mathrm{C}_{17} \mathrm{H}_{25} \mathrm{O}_{3}$ & Calcd: 279.1960 for $\mathrm{C}_{17} \mathrm{H}_{27} \mathrm{O}_{3}$ \\
\hline UV $\lambda_{\max }(\mathrm{MeOH}) \mathrm{nm}(\varepsilon)$ & $217(7,728), 276(855)$ & 218 (9,535), $277(1,084)$ \\
\hline $\mathrm{IR} v_{\max }(\mathrm{KBr}) \mathrm{cm}^{-1}$ & $\begin{array}{l}3429,2927,2341,1707 \\
1630,1090,1057\end{array}$ & $\begin{array}{l}3427,2972,2881,2364 \\
1622,1109,1057,1018\end{array}$ \\
\hline
\end{tabular}

of proton signals at $\mathrm{H}-5\left(\delta_{\mathrm{H}} 6.83\right), \mathrm{H}-7\left(\delta_{\mathrm{H}} 7.00\right)$ and $\mathrm{H}-8\left(\delta_{\mathrm{H}} 7.01\right)$. The ${ }^{1} \mathrm{H}-{ }^{1} \mathrm{H}$ COSY of 2 indicated the alignments from $\mathrm{C}-1$ to $\mathrm{C}-3$ and from $10-\mathrm{CH}_{3}$ to $\mathrm{C}-14$ (Figure 3). The connection of these partial structures was deduced from the observation of the HMBC correlations as shown in Figure 3. The correlations from $\mathrm{H}-3\left(\delta_{\mathrm{H}} 4.97\right)$ to C-4 $\left(\delta_{\mathrm{C}} 136.5\right)$ and C-9 $\left(\delta_{\mathrm{C}} 138.3\right)$, from $\mathrm{H}-10\left(\delta_{\mathrm{H}} 2.90\right)$ to C-4, C-8 $\left(\delta_{\mathrm{C}} 129.0\right)$ and C-9, and from $10-\mathrm{CH}_{3}\left(\delta_{\mathrm{H}} 1.18\right)$ to $\mathrm{C}-9$ revealed the connection between C-3 and C-4, and between C-9 and C-10. The correlations from $6-\mathrm{CH}_{3}\left(\delta_{\mathrm{H}} 2.29\right)$ to $\mathrm{C}-5\left(\delta_{\mathrm{C}} 124.5\right)$, C-6 $\left(\delta_{\mathrm{C}} 135.8\right)$ and $\mathrm{C}-7\left(\delta_{\mathrm{C}} 127.5\right)$ indicated $6-\mathrm{CH}_{3}$ is attached to $\mathrm{C}-6$. The correlations from $\mathrm{H}-11\left(\delta_{\mathrm{H}} 3.60\right)$ to $\mathrm{C}-3\left(\delta_{\mathrm{C}} 78.6\right)$ indicated the linkage of
C-3 and C-11 through an oxygen atom to form a tetrahydro- $2 \mathrm{H}$-pyran ring. Thus, the planar structure of $\mathbf{2}$ was elucidated as shown in Figure 3 , and it was designated as panowamycin $\mathrm{B}$.

The relative configuration of 2 was elucidated by ${ }^{1} \mathrm{H}-{ }^{1} \mathrm{H}$ coupling constant and ROESY experiments (Figure 4). The ROESY correlations were observed for $\mathrm{H}-3 / \mathrm{H}-11, \mathrm{H}-10 / \mathrm{H}-11$ and $10-\mathrm{CH}_{3} /$ $\mathrm{H}-12$. Moreover, a large vicinal coupling constant $(J=9.0 \mathrm{~Hz})$ and a small coupling constant $(J=2.4 \mathrm{~Hz})$ were observed between $\mathrm{H}-11$ and $\mathrm{H}-12$ and between $\mathrm{H}-10$ and $\mathrm{H}-11$, respectively. These results suggested that 2 has the relative configuration of $3 S^{\star}, 10 R^{\star}, 11 S^{\star}$ (Figure 1). 
Table $2{ }^{1} \mathrm{H}$ and ${ }^{13} \mathrm{C}$ NMR spectral data of panowamycins $\mathrm{A}(1)$ and $\mathrm{B}(2)$ in $\mathrm{CDCl}_{3}$

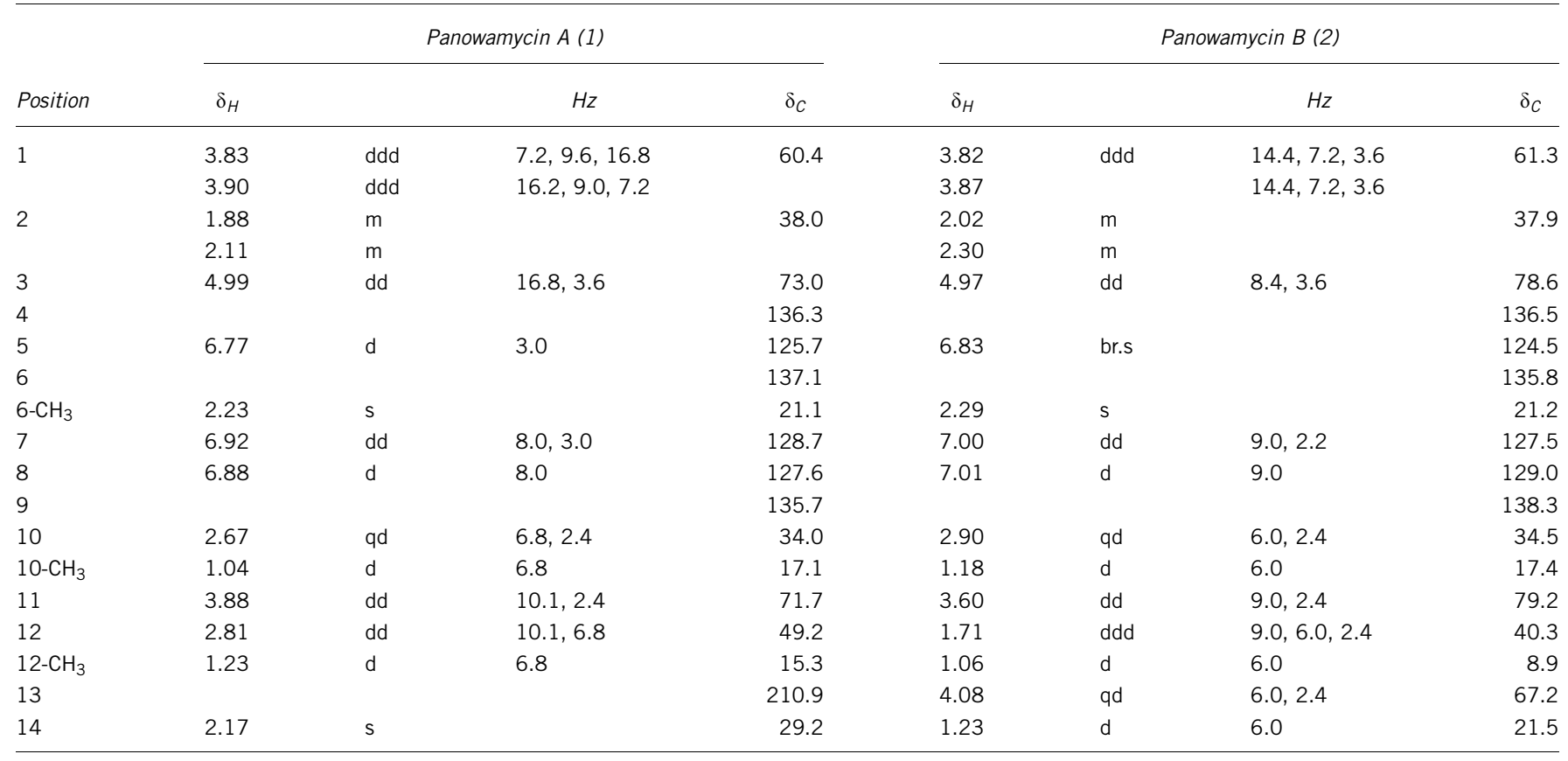

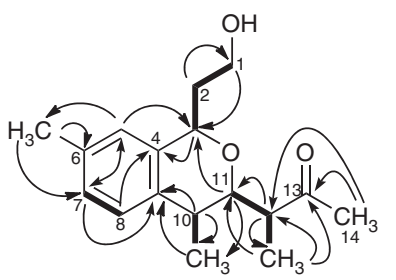

Panowamycin A (1)

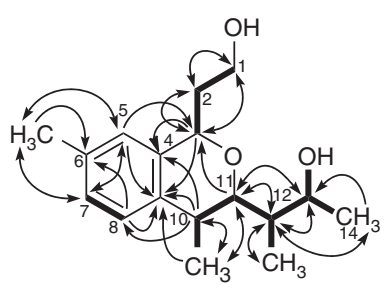

Panowamycin B (2)

\section{COSY \\ ๑ $\mathrm{HMBC}$}

Figure 3 COSY and HMBC correlations of panowamycins A (1) and B (2).

\section{Structure elucidation of 1}

The molecular formula of $\mathbf{1}$ was elucidated by HR-FAB-MS to be $\mathrm{C}_{17} \mathrm{H}_{24} \mathrm{O}_{3}$, indicating that $\mathbf{1}$ had lost two hydrogen atoms from 2 . The ${ }^{1} \mathrm{H}$ and ${ }^{13} \mathrm{C}$ NMR spectra data of $\mathbf{1}$ are listed in Table 2, and they were similar to those of 2 . However, one ketone carbonyl carbon at $\delta_{\mathrm{c}} 210.9$ was observed in $\mathbf{1}$ instead of the oxygenated $s p^{3}$ methine carbon of 2 . The ${ }^{13} \mathrm{C}-{ }^{1} \mathrm{H}$ long-range couplings of ${ }^{2} J$ and ${ }^{3} J$ in the HMBC experiments are shown in Figure 3, giving the following results. The crosspeaks from $14-\mathrm{H}_{3}\left(\delta_{\mathrm{H}} 2.17\right)$ and $12-\mathrm{CH}_{3}\left(\delta_{\mathrm{H}} 1.23\right)$ to carbonyl carbon $\left(\delta_{\mathrm{C}} 210.9\right)$ indicated that $\mathbf{1}$ has a ketone group instead of the hydroxyl group of $\mathbf{2}$ at $\mathrm{C}-13$. Therefore, the structure of $\mathbf{1}$ was elucidated as shown in Figure 3, and designated as panowamycin A.

The relative configuration of 1 was elucidated by ${ }^{1} \mathrm{H}-{ }^{1} \mathrm{H}$ coupling constant and ROESY experiments (Figure 4). The ROESY correlations were observed for $\mathrm{H}-3 / \mathrm{H}-11, \mathrm{H}-10 / \mathrm{H}-11$ and $10-\mathrm{CH}_{3} / \mathrm{H}-12$. Moreover, a large vicinal coupling constant $(J=15.6 \mathrm{~Hz})$ and a small coupling constant $(J=2.4 \mathrm{~Hz})$ were observed between $\mathrm{H}-11$ and $\mathrm{H}-12$, and between $\mathrm{H}-10$ and $\mathrm{H}-11$, respectively. Therefore, the relative configuration of 1 was determined to be $3 S^{\star}, 10 R^{\star}, 11 S^{\star}$, which was the same as that of 2 .

\section{Biological activities}

Antitrypanosomal activity of the isolated compounds was evaluated using Trypanosoma brucei brucei GUTat 3.1 strain (Table 3). We have also evaluated the antitrypanosomal activity of other polynactins, nonactin (9), monactin (10), trinactin (12) and tetranactin (13), isolated from a culture broth of Streptomyces sp. A00582 and together with dinactin (11). As a result, these compounds were classified into three groups as follows: (i) Panowamycins A (1) and B (2), NFAT-133 (3), conglobatin (4), piericidin $\mathrm{C}_{1}(5)$ and 9 showed antitrypanosomal activity with $\mathrm{IC}_{50}$ values of $0.40-5.38 \mu \mathrm{g} \mathrm{ml}^{-1}$, which was in a similar range to that of the commonly-used therapeutic drugs, suramin and eflornithine. These compounds, except 9, exhibited weak cytotoxicity against MRC-5 cells, with $\mathrm{IC}_{50}$ values of $2.95-21 \mu \mathrm{g} \mathrm{ml}^{-1}$. A Selectivity Index (SI) was created to allow direct comparisons of effectiveness and cytotoxicity. Compounds 1-5 showed SIs of 3.8-8.7. (ii) Compounds 10-13 showed potent antitrypanosomal activity, with $\mathrm{IC}_{50}$ values of $0.021-0.42 \mu \mathrm{g} \mathrm{ml}^{-1}$. However, they also showed potent or moderate cytotoxicity, with $\mathrm{IC}_{50}$ values of $0.18-0.26 \mu \mathrm{g} \mathrm{ml}^{-1}$. Among them, 10 had moderate selectivity (SI of 12). (iii) Piericidins $\mathrm{C}_{2}(\mathbf{6}), \mathrm{C}_{3}(7)$ and $\mathrm{C}_{4}(\mathbf{8})$ showed potent antitrypanosomal activity, with $\mathrm{IC}_{50}$ values of $0.34-0.48 \mu \mathrm{g} \mathrm{ml}^{-1}$ and low cytotoxicity. They demonstrated high selectivity (SIs of 71-88), in excess of those of the commonly used drugs and 10-20-fold stronger than panowamycins.

\section{DISCUSSION}

Streptomyces sp. K07-0010 produced at least nine compounds, which were observed to fit into four groups based on their molecular skeletons. It is interesting that a single microorganism simultaneously produces metabolites with a wide variety of different skeletal structures.

Among them, we found $\mathbf{1}$ and $\mathbf{2}$. Their structures are similar to that of 3, which was reported to inhibit NFAT-dependent transcription. ${ }^{6}$ Panowamycins might be formed from 3 by an intramolecular cyclization between C-3 of olefine and the hydroxyl group at C-11. Though 1 was listed in the CAS Registry file (Registry No. 1217652-79-3), there are no published data or no reports on its stereochemistry. 


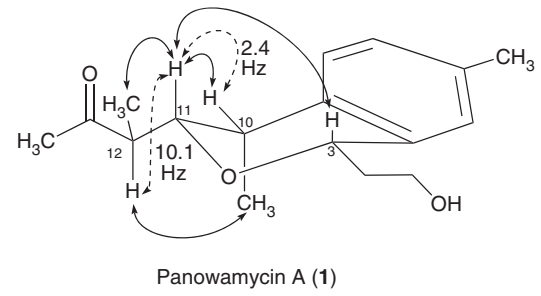

Figure 4 Relative configuration of panowamycins A (1) and B (2).

Table 3 In vitro antitrypanosomal activity against Trypanosoma brucei brucei GUTat 3.1 and cytotoxicity in MRC-5 cells of compounds isolated from a culture broth of Streptomyces sp. K07-0010

\begin{tabular}{|c|c|c|c|}
\hline \multirow[b]{2}{*}{ Compound } & \multicolumn{2}{|l|}{$I_{50}\left(\mu g m^{-1}\right)$} & \multirow[b]{2}{*}{$\begin{array}{l}\text { Selectivity index } \\
\text { MRC-5/GUTat } 3.1\end{array}$} \\
\hline & $\begin{array}{c}\text { Antitrypanosomal activity } \\
\text { T. b. b. GUTat } 3.1\end{array}$ & $\begin{array}{l}\text { Cytotoxicity } \\
\text { MRC-5 }\end{array}$ & \\
\hline Panowamycin A (1) & 0.40 & 2.95 & 7.4 \\
\hline Panowamycin B (2) & 3.30 & 13 & 3.8 \\
\hline NFAT-133 (3) & 2.78 & 21 & 7.5 \\
\hline Conglobatin (4) & 2.46 & 13 & 5.2 \\
\hline Piericidin $C_{1}(5)$ & 0.44 & 3.81 & 8.7 \\
\hline Piericidin $\mathrm{C}_{2}$ (6) & 0.48 & 42 & 88 \\
\hline Piericidin $C_{3}(7)$ & 0.34 & 24 & 71 \\
\hline Piericidin $\mathrm{C}_{4}$ (8) & 0.37 & 28 & 76 \\
\hline Nonactin (9) & 5.38 & 0.15 & 0.03 \\
\hline Monactin (10) & 0.021 & 0.26 & 12 \\
\hline Dinactin (11) & 0.065 & 0.21 & 3.2 \\
\hline Trinactin (12) & 0.27 & 0.20 & 0.7 \\
\hline Tetranactin (13) & 0.42 & 0.18 & 0.4 \\
\hline Eflornithine $^{a}$ & 2.27 & $>100$ & $>44$ \\
\hline Suramin ${ }^{a}$ & 1.58 & $>100$ & $>63$ \\
\hline
\end{tabular}

aClinically used antitrypanosomal drugs.

Regarding the antitrypanosomal activity, as shown in Table 3, piericidins $\mathrm{C}_{2}, \mathrm{C}_{3}$ and $\mathrm{C}_{4}$ had the more potent activity and best SI. It was previously reported that piericidins are inhibitors of $\mathrm{NADH}$ dehydrogenase in the mitochondrial respiratory chain. ${ }^{12}$ We reported that some inhibitors of the mitochondrial respiratory chain, such as leucinostatins, ${ }^{13}$ trichosporins ${ }^{4}$ and citreoviridin, ${ }^{5}$ also showed potent antitrypanosomal activity. Therefore, it is likely that all these compounds possess a similar mode of action.

Compounds 1-3 showed moderate activity. Compound 1 showed more potent antitrypanosomal activity and better SI than 2, and therefore the ketone group at $\mathrm{C}-13$ of $\mathbf{1}$ is probably essential for the activity.

\section{METHODS}

General experiments

All solvents (EtOAc, $\mathrm{CHCl}_{3}, \mathrm{MeOH}$ and $\mathrm{CH}_{3} \mathrm{CN}$ ) and $\mathrm{Na}_{2} \mathrm{SO}_{4}$ were purchased from Kanto Chemical (Tokyo, Japan). Silica gel was purchased from Merck (Darmstadt, Germany). Pegasil ODS was obtained from Senshu Scientific Co. (Tokyo, Japan). LH-20 gel was purchased from GE Healthcare (Buckinghamshire, England, UK).

NMR spectra were measured using a Varian XL-400 spectrometer or an Inova 600 spectrometer (Agilent Technologies, Santa Clara, CA, USA), with ${ }^{1} \mathrm{H}$ NMR at 400 or $600 \mathrm{MHz}$ and ${ }^{13} \mathrm{C}$ NMR at 100 or $150 \mathrm{MHz}$ in $\mathrm{CDCl}_{3}$. The

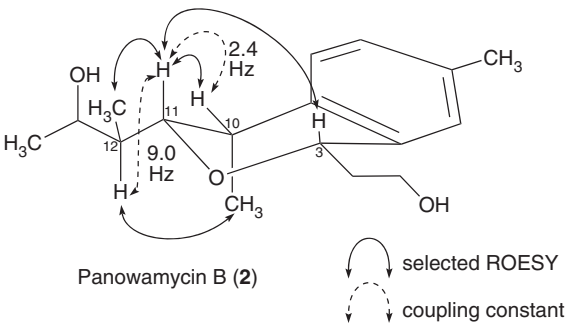

chemical shifts are expressed in p.p.m. and are referred to $\mathrm{CHCl}_{3}$ (7.26 p.p.m.) in the ${ }^{1} \mathrm{H}$ NMR spectra and to $\mathrm{CDCl}_{3}$ (77.0 p.p.m.) in the ${ }^{13} \mathrm{C}$ NMR spectra. FAB-MS spectra were measured on a JMS AX-505 HA mass spectrometer (JEOL, Akishima, Japan). IR spectra ( $\mathrm{KBr}$ ) were taken on a FT-210 Fourier transform infrared spectrometer (Horiba, Kyoto, Japan). UV spectra were measured with a DU640 spectrophotometer (Beckman Coulter, Brea, CA, USA). Optical rotation was measured on a model DIP-181 polarimeter (JASCO, Hachioji, Japan).

\section{Taxonomic studies}

The International Streptomyces Project media recommended by Shirling and Gottlieb $^{14}$ and media recommended by Waksman ${ }^{15}$ were used to investigate the cultural characteristics. Cultures were observed after incubation for 2 weeks at $27^{\circ} \mathrm{C}$. Morphological properties were observed with a scanning electron microscope (model JSM-5600, JEOL). Isomers of diaminopimelic acid in whole-cell hydrolysates were determined by TLC following the standard methods of Becker et al. ${ }^{16}$ and Hasegawa et al. ${ }^{17} 16 \mathrm{~S}$ rDNA was amplified by PCR and sequenced directly on an ABI model 377A automatic DNA sequencer using a PRISM Ready Reaction Dye Primer Cycle Sequencing Kit (Applied Biosystems, Carlsbad, CA, USA).

\section{Fermentation}

Strain K07-0010 was grown and maintained on agar slants consisting of 1.0\% starch (Wako Pure Chemical Industries, Osaka, Japan), 0.3\% NZ amine (Wako Pure Chemical Industries), $0.1 \%$ yeast extract (Oriental Yeast, Tokyo, Japan), $0.1 \%$ meat extract (Kyokuto Pharmaceutical Industrial, Tokyo, Japan), $1.2 \%$ agar (SSK Sales, Shizuoka, Japan) and $0.3 \% \mathrm{CaCO}_{3}$ (Kanto Chemical). A loop of spores of strain K07-0010 was inoculated into $100 \mathrm{ml}$ of seed medium, consisting of $2.4 \%$ starch, $0.1 \%$ glucose (Wako Pure Chemical Industries), $0.3 \%$ peptone (Kyokuto Pharmaceutical Industrial), $0.3 \%$ meat extract, $0.5 \%$ yeast extract and $0.4 \% \mathrm{CaCO}_{3}$ (adjusted to $\mathrm{pH} 7.0$ before sterilization) in a 500-ml Erlenmeyer flask. The flask was incubated on a rotary shaker ( 210 r.p.m.) at $27^{\circ} \mathrm{C}$ for 3 days. A $1-\mathrm{ml}$ portion of the seed culture was transferred to 500-ml Erlenmeyer flasks (total 32), each containing $100 \mathrm{ml}$ of production medium, consisting of $2.0 \%$ glycerol (Kanto Chemical), $1.0 \%$ glucose, $0.5 \%$ corn steep powder, $1.0 \%$ soybean, $0.2 \%$ meat extract, $0.01 \%$ $\mathrm{MgSO}_{4} \cdot 7 \mathrm{H}_{2} \mathrm{O}$ (Wako Pure Chemical Industries) and $0.2 \% \mathrm{CaCO}_{3}$ (adjusted to $\mathrm{pH} 7.0$ before sterilization) and fermentation was carried out on a rotary shaker (210 r.p.m.) at $27^{\circ} \mathrm{C}$ for 6 days.

\section{Antitrypanosomal activity in vitro}

In vitro antitrypanosomal activities against $T . \quad b . \quad b$. strain GUTat 3.1 were measured, using the method described previously. ${ }^{18}$ This strain, donated by Dr Y Yabu (Nagoya City University, Japan), is a clone derivative of a stock EVE (Edinburgh Veterinary Expedition) 10 that was originally isolated in 1966 from a naturally infected bovine in Uganda.

\section{Cytotoxic activity in vitro}

Measurement of cytotoxic activity against human fetal lung fibroblast MRC-5 cells was carried out as described previously. ${ }^{19}$ 
Isolation of macrotetrolides from the culture broth of Streptomyces sp. A00582

Macrotetrolides, including 11, were isolated from the culture broth of Streptomyces sp. A00582 supplied by the Marine Biotechnology Institute, Kitasato Unversity. They were extracted by ethyl acetate and successively washed by $n$-butanol, methanol and $n$-hexane. The insoluble material was then purified by silica gel and LH-20 column chromatography and HPLC. Compounds 9-13 were identified by 2D NMR and MS analysis.

\section{ACKNOWLEDGEMENTS}

This study was supported, in part, by funds from the Drugs for Neglected Diseases initiative (DNDi), Quality Assurance Framework of Higher Education from the Ministry of Education, Culture, Sports, Science and Technology (MEXT), Japan, and All Kitasato Project Study (AKPS). We are grateful to Ms Hitomi Sekiguchi and Mr Toshiaki Furusawa for their technical assistance, Ms Akiko Nakagawa, Dr Kenichiro Nagai and Ms Noriko Sato, School of Pharmacy, Kitasato University for measurements of mass and NMR spectra, and Dr Yoshikazu Shizuri and Ms Atsuko Katsuta, Marine Biotechnology Institute for the macrotetrolide-producing actinomycete strain.

1 World Health Organization African trypanosomiasis (sleeping sickness) Fact Sheet No. 259 (2010). http://www.nzdl.org/.

2 Brun, R., Blum, J., Chappuis, F. \& Burri, C. Human African trypanosomiasis. Lancet 375, 148-159 (2010).

3 Niitsuma, M. et al. Sinefungin VA and dehydrosinefungin V, new antitrypanosomal antibiotics produced by Streptomyces sp. K05-0178. J. Antibiot. 63, 673-679 (2010).
4 Iwatsuki, M. et al. Antitrypanosomal peptaibiotics, trichosporins B-VIla and B-VIIb, produced by Trichoderma polysporum FKI-4452. J. Antibiot. 63, 331-333 (2010).

5 Hashida, J. et al. Pyrenocine I, a new pyrenocine analog produced by Paecilomyces sp. FKI-3573. J. Antibiot. 63, 559-561 (2010).

6 Burres, N. S. et al. Simple aromatics identified with a NFAT-lacZ transcription assay for the detection of immunosuppressants. J. Antibiot. 48, 380-386 (1995).

7 Westley, J. W. et al. Conglobatin, a novel macrolide dilactone from Streptomyces conglobatus ATCC 31005. J. Antibiot. 32, 874-877 (1979).

8 Yoshida, S. et al. Chemical structures of new piericidins produced by Streptomyces pactum. Agric. Biol. Chem. 41, 855-862 (1977).

9 Beck, J. et al. Stoffwechselprodukte von Actinomyceten 35. Mitteilung. Über die Konstitution der Makrotetrolide Monactin, Dinactin und Trinactin. Helv. Chim. Acta 45, 620-630 (1962).

10 EzTaxon server $2.1 \mathrm{http}: / / 147.47 .212 .35: 8080 /$.

11 Williams, S. T., Goodfellow, M. \& Alderson, G. in Bergey's Manual of Systematic Bacteriology Vol. 4. (ed. Wiliams, S. T. et al.) 2452-2492 (Williams \& Wilkins, Baltimore, 1989).

12 Fung, J. et al. Isolation and characterization of complex I, rotenone-sensitive NADH: ubiquinone oxidoreductase, from the procyclic forms of Trypanosoma brucei. Eur. J. Biochem. 268, 3075-3082 (2001).

13 Ishiyama, A. et al. In vitro and in vivo antitrypanosomal activities of three peptide antibiotics: leucinostatin $\mathrm{A}$ and $\mathrm{B}$, alamethicin $\mathrm{I}$ and tsushimycin. J. Antibiot. 62, 303-308 (2009).

14 Shiring, E. B. \& Gottlieb, D. Methods for characterization of Streptomyces species. Int. J. Syst. Bacteriol. 16, 313-340 (1966).

15 Waksman, S. A. (ed.). in The Actinomycetes Vol. 2 (Williams and Wilkins, Baltimore, 1961).

16 Becker, B., Lechevalier, M. P. \& Lechevalier, H. A. Chemical composition of cell-wall preparation from strains of various form-genera of aerobic actinomycetes. Appl. Microbiol. 13, 236-243 (1965).

17 Hasegawa, T., Takizawa, M. \& Tanida, S. A rapid analysis for chemical grouping of aerobic actinomycetes. J. Gen. Appl. Microbiol. 29, 319-322 (1983).

18 Otoguro, K. et al. Selective and potent in vitro antitrypanosomal activities of 10 microbial metabolites. J. Antibiot. 61, 327-378 (2008).

19 Otoguro, K. et al. Potent antimalarial activities of the polyether antibiotic, X-206. J. Antibiot. 54, 658-663 (2001). 